\title{
Serological diagnosis of gonorrhoea by an enzyme-linked immunosorbent assay (Elisa)
}

\author{
A. A. GLYNN AND CATHERINE ISON \\ From the Department of Bacteriology, Wright-Fleming Institute, \\ St Mary's Hospital Medical School, London
}

SUMMARY IgG antibody to an outer membrane protein extracted from Neisseria gonorrhoeae was measured in patients with gonorrhoea. The level in such patients was significantly higher than in normal controls or in patients with other conditions who were attending the clinic for sexually transmitted diseases. Significantly higher antibody levels were detectable in half the patients within a few days of infection and in a similar proportion of carriers-both male and female. Men with rectal gonorrhoea had particularly high antibody levels. Sixteen per cent of presumptively normal men and $11 \%$ of normal women gave positive results but the actual false positive rate could be lower.

\section{Introduction}

Despite widespread efforts, especially recently, there is still no satisfactory serological test for diagnosing gonorrhoea (Watt et al., 1971). The ultimate criterion of gonococcal infection is that Neisseria gonorrhoeae can be isolated from a patient, and this will remain the criterion. The difficulties in culturing gonococci and the problems of obtaining satisfactory specimens for culture make it desirable that an accurate method of serodiagnosis be available for individuals, particularly for screening populations.

The specificity of a serological test is usually inversely related to its sensitivity, but modern methods of antibody detection have greatly increased the general level of sensitivity at which this paradox occurs. It is essential, therefore, to find a suitable antigen. Because of its chemical stability, and hence ease of preparation, gonococcal lipopolysaccharide has often been used (Maeland and Larsen, 1971; Ward and Glynn, 1972).

However, the number of antigenically determinant sugars in gonococcal lipopolysaccharide is small (Perry et al., 1975; Stead et al., 1975), which may explain why positive reactions are sometimes found in uninfected people, presumably owing to crossreacting antibody formed against non-pathogenic

Address for reprints: Professor A. A. Glynn, Department of Bacteriology, Wright-Fleming Institute, St Mary's Hospital Medical School, London W2 1 PG

Received for publication 21 September 1977
Neisseria and other organisms (Glynn and Ward, 1970).

Gonococcal pili are much more specific antigens and the radioimmunoassay for antibody to pili introduced by Buchanan et al. (1973) is potentially of great value, although it has so far been evaluated only to a limited extent (Oates et al., 1977).

The preliminary findings of an investigation into the use of an enzyme-linked immunosorbent assay (Elisa) to detect antibodies to an outer membrane protein of $N$. gonorrhoeae in patients with gonorrhoea are reported.

\section{Methods}

\section{POPULATIONS}

Sera were obtained from six groups of people (Table 1). The gonococcal group consisted of patients attending the clinic for sexually transmitted diseases (STDs) from whom $N$. gonorrhoeae had been identified by culture or smear or both. The non-gonococcal group comprised patients attending the same clinic but from whom no $N$. gonorrhoeae had been identified. Some had non-specific urethritis or herpes infection, some were simply anxious, and others were being followed-up from an earlier attack of gonorrhoea (Table 6).

Cultures were taken from the cervix of all female patients; in the males all urethral exudates were examined microscopically but only 45 were cultured. The reason for culture in men varied, but it was often the presence of rectal symptoms or some unusual 
Table 1 Populations studied

\begin{tabular}{|c|c|c|c|c|c|c|c|c|c|}
\hline \multirow{3}{*}{ Group } & \multicolumn{3}{|l|}{ Men } & \multicolumn{3}{|c|}{ Women } & \multicolumn{3}{|c|}{ Total } \\
\hline & \multirow[t]{2}{*}{ No. } & \multicolumn{2}{|c|}{ Age (years) } & \multirow[t]{2}{*}{ No. } & \multicolumn{2}{|c|}{ Age (years) } & \multirow[t]{2}{*}{ No. } & \multicolumn{2}{|c|}{ Age (years) } \\
\hline & & Mean & Range & & Mean & Range & & Mean & Range \\
\hline $\begin{array}{l}\text { Normal controls } \\
\text { Patients without gonorrhoea } \\
\text { Patients with gonorrhoea } \\
\text { Total }\end{array}$ & $\begin{array}{r}106 \\
84 \\
191 \\
381\end{array}$ & $\begin{array}{l}21 \\
31 \\
30 \\
28\end{array}$ & $\begin{array}{l}18-36 \\
17-61 \\
17-56 \\
17-61\end{array}$ & $\begin{array}{r}131 \\
94 \\
212 \\
437\end{array}$ & $\begin{array}{l}24 \\
26 \\
23 \\
24\end{array}$ & $\begin{array}{l}15-43 \\
16-61 \\
15-50 \\
15-61\end{array}$ & $\begin{array}{l}237 \\
178 \\
403 \\
818\end{array}$ & $\begin{array}{l}23 \\
28 \\
26 \\
26\end{array}$ & $\begin{array}{l}15-43 \\
16-61 \\
15-56 \\
15-61\end{array}$ \\
\hline
\end{tabular}

feature. It is not possible, therefore, to draw any general conclusions from this group on the relationship between cultural and smear results in straightforward urethritis.

The sera used were from those sent routinely for serological tests for syphilis. All the sera from patients with proved gonorrhoea were taken on given days for a period of several months. During a further period all sera sent from the STD clinic were examined.

Normal control sera were from patients attending the antenatal clinic and from male and female students to whom the purpose of the investigation had been explained. About half the students approached agreed to take part. As individual results would not be disclosed, there was no reason why a student who had had gonorrhoea should not have been willing to volunteer although some may have refrained.

\section{PREPARATION OF ANTIGEN}

Antigen was prepared from a recently isolated strain of $N$. gonorrhoeae (H 1 ) stored in liquid nitrogen. Subcultures from this were first grown on GC agar plates containing $36 \mathrm{~g} / \mathrm{l}$ GC base agar (Difco) plus $20 \mathrm{ml} / 1$ Supplement A, containing $20 \%$ dextrose (BDH), $0.25 \% \alpha$-glutamine (Sigma), and $0.002 \%$ co-carboxylase (Sigma) plus $2 \mathrm{ml} / 1$ Supplement B, containing $0.5 \%$ ferric nitrate (Sigma). The bacteria harvested from the plates were used to seed a biphasic system (description of method to be published) consisting of dextrose starch agar (Difco), $65 \mathrm{~g} / \mathrm{l}$, reinforced by Bacto-agar (Difco), $10 \mathrm{~g} / \mathrm{l}$, covered by proteose peptone (Difco) plus Supplements A and B, and shaken for six or seven hours.

The growth from all flasks was checked for purity by Gram's stain, harvested by centrifugation at $6000 \times g$ for 15 minutes, pooled and washed twice in phosphate buffered saline (PBS), and again centrifuged. The wet weight was recorded and the pellet stored at $-20^{\circ} \mathrm{C}$.

An outer membrane protein antigen was prepared as described by Smyth et al. (1976). Twenty grams wet weight of $N$. gonorrhoeae were lysed, the cell envelopes separated by centrifugation and extracted with TritonX100 followed by desoxycholate. The desoxycholate fraction was used and will be referred to hereafter as the antigen. The antigen was stored in $100 \mu$ amounts at $-20^{\circ} \mathrm{C}$.

\section{PREPARATION OF ALKALINE}

PHOSPHATASE ANTIHUMAN IgG CONJUGATE Rabbit antihuman IgG serum was precipitated with $18 \%$ followed by $12 \%$ anhydrous sodium sulphate. The precipitate was dissolved in the smallest volume possible and the IgG fraction separated on a DEAE cellulose column.

After concentration using an Amicon filter (PM 30 size $25 \mathrm{~mm}$ ), the rabbit antibody was conjugated with alkaline phosphatase (Sigma type 7) in a 2:5 ratio as described by Voller et al. (1976).

\section{ASSAY PROCEDURE}

One hundred microlitres of antigen diluted in carbonate-bicarbonate buffer ( $\mathrm{pH} 9 \cdot 6$ ) were added to each well in a flat-bottomed microtitre plate (Cooke M29AR, Dynatek Laboratories), using a Compu-pet 100 (General Diagnostic), and incubated at room temperature for 30 minutes. The antigen was then tipped out and the plates were washed by refilling with PBS-Tween (PBS pH 7.4+ $0.05 \%$ Tween 20 ). This was left for three minutes, and the washing repeated three times. The test sera were diluted 1:1000 in PBS-Tween, and $200 \mu \mathrm{l}$ of each were added to an antigen-coated tray. Each serum was tested in duplicate. Trays were incubated in moist conditions for one hour at $30^{\circ} \mathrm{C}$. They were then washed three times in PBS-Tween as before.

The antihuman IgG alkaline phosphatase conjugate was diluted to its working strength in PBSTween, $200 \mu l$ were added to each well, and the trays incubated for two hours.

The trays were again washed three times in PBS-Tween and $200 \mu \mathrm{l}$ substrate $(1 \mathrm{mg} / \mathrm{ml} \mathrm{p}$-nitrophenyl phosphate (Sigma)) in $10 \%$ diethanolamine (BDH) buffer (pH 9.8) were added to each well for exactly 30 minutes. The reaction was stopped by adding $50 \mu \mathrm{l}$ of $1 \mathrm{~mol} / \mathrm{l}$ sodium hydroxide and the colour reaction in each well was read at $405 \mathrm{~nm}$. 
Samples of a negative and positive control serum were tested in duplicate in each tray.

The negative control serum was a pool of sera from five male and five female students. The positive control was taken from a patient with gonococcal arthritis and it was used at a dilution of 1 in 2000.

Results were expressed as corrected extinction values $\mathrm{E}_{\mathrm{cr}}$ calculated as

$$
E_{c r}=\left(E_{t}-E_{n}\right) \times \frac{\text { mean }\left(E_{p}-E_{n}\right)}{\left(E_{p}-E_{n}\right) \text { on test day }} \times 100
$$

where $E_{t}, E_{p}$, and $E_{n}$ are the extinction values $(\lambda=405$ $\mathrm{nm})$ of the unknown and positive and negative control sera. The mean $\left(E_{p}-E_{n}\right)$ is the mean difference between the positive and negative control sera measured in 20 assays during a period of months.

\section{STANDARDISATION OF ANTIBODY ASSAY}

It is important in the Elisa technique that there should be an excess of antigen. Dilutions of known positive and negative sera were tested against increasing antigen concentrations. In the example shown (Fig. 1), a plateau was reached at concentrations of antigen above $20 \mu \mathrm{g}$ protein $/ \mathrm{ml}$. The actual concentration of antigen varied with the batch of antigen and its age but it was always in the plateau range. For each new preparation of antigen the concentration was adjusted so as to keep the difference constant between the standard control positive and negative sera. Similar adjustments were made to the concentration of each new batch of enzyme-conjugated antihuman IgG.

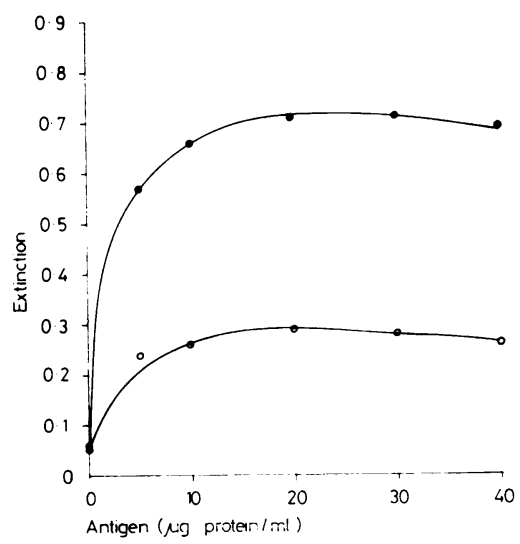

Fig. 1 Effect of antigen concentration on extinction (antibody level).

Positive control serum

Negative control serum
For routine tests a standard dilution of unknown sera of 1:1000 was chosen (Fig. 2). This gave a small but readable extinction value with normal sera and it still allowed most positive sera to be read without further dilution-that is, to give $E_{405}$ of less than $1 \cdot 0$.

Fourteen test sera plus the sera from positive and negative controls were assayed 20 times during a period of a week. The results showed a $20 \%$ coefficient of variation. Variation between days was greater than variation between different trays done on the same day.

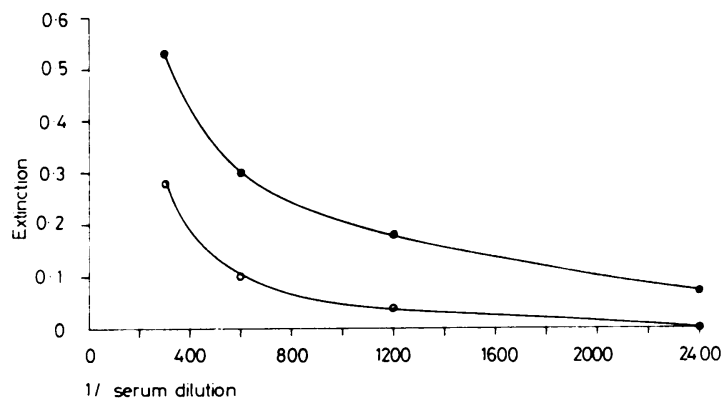

Fig. 2 Effect of diluting serum on extinction.

Positive control serum

Negative control serum

\section{ANALYSIS OF RESULTS}

The results were analysed with the help of a CDC 6600 computer at the University of London computer centre using statistical and other programs from the Statistical Package for the Social Sciences (SPSS) (Nie et al., 1975).

Student's $t$ test was used for Table 2 and an analysis of variance for Table 6.

\section{Results}

POPULATIONS

The number of people in each group and their age distribution is given in Table 1. Although there are some differences in age distribution, in no group was antibody activity affected by age.

\section{ANTIBODY ACTIVITY BY GROUPS}

There were no significant differences in mean antibody levels between men and women in comparable groups, but for either sex the mean for patients with gonorrhoea was significantly higher than that for control subjects (Table 2 ). In the normal groups the frequency distribution (Figs 3 and 4) showed marked clumping at the bottom of the scale with a few isolated high readings. The antibody levels in patients 
Table 2 Antibody activity $\left(E_{\mathrm{cr}}\right)$ by groups

\begin{tabular}{|c|c|c|c|c|}
\hline \multirow{2}{*}{ Group } & \multicolumn{2}{|l|}{ Men } & \multicolumn{2}{|l|}{ Women } \\
\hline & Mean $E_{\mathrm{cr}}$ & $(S E)$ & Mean $E_{\mathrm{cr}}$ & $(S E)$ \\
\hline $\begin{array}{l}\text { Normal controls } \\
\text { Patients without gonorrhoea } \\
\text { Patients with gonorrhoea }\end{array}$ & $\begin{array}{l}10 \cdot 1^{\mathrm{a}} \\
11 \cdot 8^{\mathrm{c}} \\
30 \cdot 5^{\mathrm{e}}\end{array}$ & $\begin{array}{l}(1 \cdot 3) \\
(1 \cdot 3) \\
(2 \cdot 4)\end{array}$ & $\begin{array}{l}10 \cdot 0^{b} \\
11 \cdot 4^{d} \\
34 \cdot 5^{i}\end{array}$ & $\begin{array}{l}(1 \cdot 8) \\
(1 \cdot 8) \\
(2 \cdot 7)\end{array}$ \\
\hline
\end{tabular}

Student's $t$ tests

Comparing ab, cd, ef, ac, bd not significant

ae )

$\left.\begin{array}{l}\text { ce } \\ \text { bf } \\ \text { df }\end{array}\right\} P<0.0001$

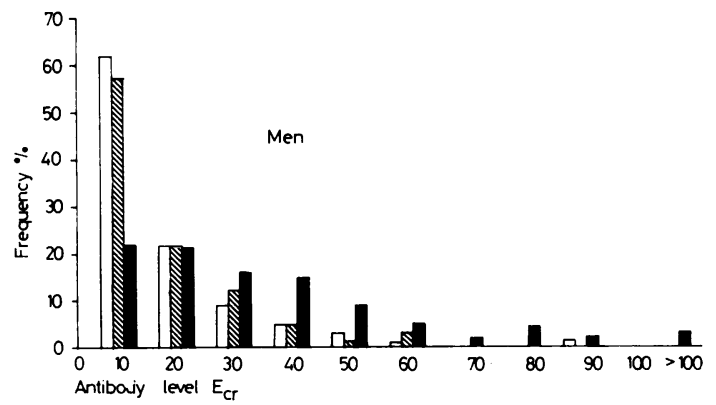

Fig. 3 Frequency distribution of antibody levels

(Ecr units) in men.

Normal controls $\square$

Patients with conditions other than gonorrhoea

Patients with gonorrhoea

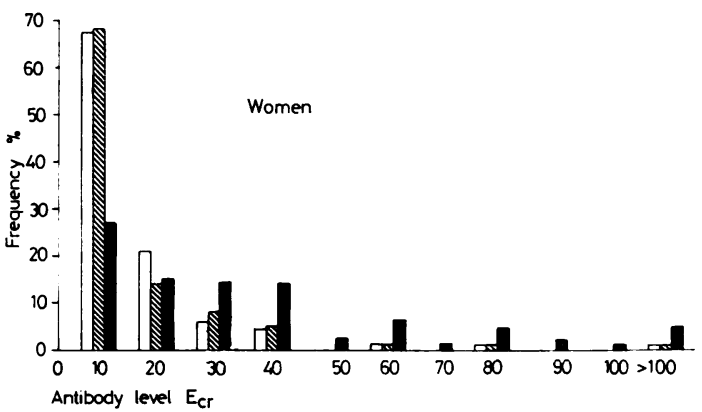

Fig. 4 Frequency distribution of antibody levels (Ecr units) in women.

Normal controls $\square$

Patients with conditions other than gonorrhoea $\lesssim$

Patients with gonorrhoea

with gonorrhoea were more evenly distributed across the whole range.

In both sexes the patients with conditions other than gonorrhoea from the STD clinic did not differ significantly in means or in frequency distribution from the normal controls.

\section{ANTIBODY LEVELS IN INDIVIDUALS}

Although the gonococcal patients as a group had significantly higher antibody levels than the normal subjects, the two groups overlapped. Whereas means are useful to compare populations, the clinical interpretation of antibody level in an individual patient is best considered in relation to the cumulative frequencies (Table 3 ). If an antibody level of 15 or more $E_{c r}$ units is taken as abnormal, $16 \%$ of our normal male population would give false positive results and $11 \%$ would do so in the female.

This percentage could be reduced to $8.5 \%$ for both sexes if the abnormal range was raised to 20 or more $E_{c r}$ units, but after that the reduction would be negligible. The 'false' positive results may be caused by extreme variation in a normal population, perhaps the result of stimulation by cross-reacting antigens. However it is possible, even likely, that some at least are owing to unsuspected or undeclared gonorrhoea in a normal population.

Depending on whether 14 or $19 \mathrm{E}_{\mathrm{cr}}$ units is taken as the limit, just over or just under half the patients with proved gonorrhoea would be regarded as having an antibody response.

Table 3 Cumulative frequency ( $\%$ ) of patients by groups at different antibody levels

\begin{tabular}{|c|c|c|c|c|c|c|}
\hline \multirow{4}{*}{$\begin{array}{l}\text { Antibody } \\
\left(E_{\mathrm{cr}}\right)\end{array}$} & \multicolumn{6}{|c|}{ Cumulative frequency $(\%)$} \\
\hline & \multirow{2}{*}{\multicolumn{2}{|c|}{$\begin{array}{l}\text { Normal } \\
\text { controls }\end{array}$}} & \multicolumn{4}{|c|}{ Patients } \\
\hline & & & \multicolumn{2}{|c|}{$\begin{array}{l}\text { Without } \\
\text { gonorrhoea }\end{array}$} & \multicolumn{2}{|c|}{$\begin{array}{l}\text { With } \\
\text { gonorrhoea }\end{array}$} \\
\hline & Men & Women & Men & Women & Men & Women \\
\hline $\begin{array}{l}\geqslant 10-14 \\
\geqslant 15-19 \\
\geqslant 20-24 \\
\geqslant 25-29 \\
\geqslant 30-34\end{array}$ & $\begin{array}{r}23 \\
16 \\
8 \\
7 \\
6\end{array}$ & $\begin{array}{r}16 \\
11 \\
8 \\
6 \\
3\end{array}$ & $\begin{array}{r}25 \\
21 \\
14 \\
9 \\
6\end{array}$ & $\begin{array}{r}24 \\
18 \\
12 \\
10 \\
6\end{array}$ & $\begin{array}{l}64 \\
56 \\
47 \\
39 \\
31\end{array}$ & $\begin{array}{l}63 \\
55 \\
47 \\
41 \\
32\end{array}$ \\
\hline
\end{tabular}

\section{EFFECT OF DURATION OF INFECTION ON} ANTIBODY

Of the men with gonorrhoea, $128(88 \%)$ had had the disease for a week or less and $98(67 \%)$ for three days or less. The mean antibody level rose markedly and significantly with time $(P<0.0001)$. Conversely the numbers of false negatives fell from $51 \%$ during the first three days to $33 \%$ during the second half of the week. The pattern suggests a rapid antibody response, falling away within a week or two of treatment which was usually started on the patient's first attendance (Table 4).

Among women the pattern was different. There was no significant relationship between antibody level and duration although there was some indica- 
tion of a decrease after two or three weeks. Women were generally not seen as early as men (only $60 \%$ in the first week) and the figures may well underestimate the duration of infection (Table 5).

OTHER FACTORS AFFECTING THE

ANTIBODY LEVEL (Table 6)

In both sexes asymptomatic carriers had the same mean antibody levels as patients with gonorrhoea. The level was significantly higher in men with

Table 4 Effect of duration of present attack of gonorrhoea on antibody levels in men

\begin{tabular}{lrll}
\hline $\begin{array}{l}\text { Duration } \\
\text { (days) }\end{array}$ & No. & $\begin{array}{l}* \% \text { with antibody } \\
<20 E_{\mathrm{cr}} / \mathrm{ml}\end{array}$ & $\begin{array}{l}\text { Mean antibody } \\
\text { level }\left(E_{\mathrm{cr}} / \mathrm{ml}\right)\end{array}$ \\
\hline $1-3$ & & 51 & 23 \\
$4-7$ & 98 & 33 & 32 \\
$1-7$ & 30 & 47 & 25 \\
8 and more & 128 & 24 & 49 \\
Subtotal & 17 & 44 & 28 \\
Not known & 145 & 41 & 36 \\
Total & 46 & 43 & 30 \\
\hline
\end{tabular}

*Equivalent to $\%$ false negative

Table 5 Effect of duration of present attack of gonorrhoea on antibody levels in women

\begin{tabular}{lcll}
\hline $\begin{array}{l}\text { Duration } \\
\text { (days) }\end{array}$ & No. & $\begin{array}{l}* \% \text { with antibody } \\
<20 E_{\mathrm{cr}} / \mathrm{ml}\end{array}$ & $\begin{array}{l}\text { Mean antibody } \\
\text { level }\left(E_{\mathrm{cr}} / \mathrm{ml}\right)\end{array}$ \\
$1-3$ & 32 & 44 & 34 \\
$4-7$ & 26 & 42 & 36 \\
$1-7$ & 58 & 43 & 35 \\
8 and more & 38 & 42 & 25 \\
Subtotal & 96 & 43 & 32 \\
Not known & 116 & 47 & 36 \\
Total & 212 & 45 & 34 \\
\hline
\end{tabular}

*Equivalent to $\%$ false negative gonorrhoea who had rectal symptoms and in men with positive results to serological tests for syphilis. This finding is probably a reflection of the high incidence of syphilis among male homosexuals attending the clinic; it was not seen in the small group of women with positive results to serological tests for syphilis.

Antibody was also very high ( $60 \mathrm{E}_{\text {cr }}$ units) in two women with disseminated gonococcal infection.

Among patients without gonococcal infection the antibody level was higher if there was a history of gonorrhoea. This difference was greater in men than in women. Further analysis of the men showed that higher antibody levels were related to a previous attack of gonorrhoea within the past 12 weeks. The half-life of human IgG is 23 days so that if no further antibody was made once the infection was over, the antibody level would drop approximately 16-fold in 12 weeks. The figures also suggest that if any of the raised antibody levels found among the control subjects were in fact caused by gonorrhoea, it must have been a recent attack.

Among patients with gonorrhoea, antibody levels were not affected by a past attack. It is possible that any residual effect of a recent infection would be swamped by the antibody response of the current one.

\section{Discussion}

The Elisa technique worked smoothly and with practice one person could easily test 100 sera a day. Moreover the test could be calibrated so that the results are expressed as $\mu \mathrm{g}$ of antibody $/ \mathrm{ml}$ serum.

Table 6 Factors affecting antibody levels

\begin{tabular}{|c|c|c|c|c|c|c|c|c|}
\hline \multirow{3}{*}{ Factor } & \multicolumn{4}{|c|}{ Male patients } & \multicolumn{4}{|c|}{ Female patients } \\
\hline & \multicolumn{2}{|c|}{ With gonorrhoea } & \multicolumn{2}{|c|}{ Without gonorrhoea } & \multicolumn{2}{|c|}{ With gonorrhoea } & \multicolumn{2}{|c|}{ Without gonorrhoea } \\
\hline & No. & Mean $E_{\mathrm{cr}}$ & No. & Mean $E_{\mathrm{cr}}$ & No. & Mean $E_{\mathrm{cr}}$ & No. & Mean $E_{\mathrm{cr}}$ \\
\hline Asymptomatic carriers & 19 & 28 & - & - & 64 & 30 & - & - \\
\hline Symptoms & 168 & 28 & - & - & 143 & 33 & - & - \\
\hline \multicolumn{9}{|l|}{ Rectal symptoms } \\
\hline Yes & 23 & $39 \mathrm{a}$ & - & - & - & 一 & - & 一 \\
\hline No & 168 & $27^{b}$ & - & - & - & - & - & - \\
\hline \multicolumn{9}{|c|}{ Serological test for syphilis } \\
\hline Positive & 24 & $42 \mathrm{c}$ & 18 & 16 & 8 & 24 & 5 & 5 \\
\hline Negative & 159 & $26^{d}$ & 62 & 10 & 195 & 32 & 84 & 12 \\
\hline Doubtful & 7 & 29 & 3 & 16 & 8 & 41 & 5 & 2 \\
\hline \multicolumn{9}{|l|}{ History of gonorrhoea } \\
\hline Yes & 98 & 28 & 36 & $15^{\mathrm{e}}$ & 50 & 34 & 18 & 15 \\
\hline No & 62 & 27 & 26 & $8^{f}$ & 118 & 30 & 62 & 10 \\
\hline \multicolumn{9}{|c|}{ History of sexually transmitted } \\
\hline disease unspecified & 15 & 31 & 11 & 14 & 14 & 47 & 6 & 2 \\
\hline \multicolumn{9}{|l|}{ Time since last attack } \\
\hline$<12$ weeks & - & - & 9 & $24 \mathrm{~g}$ & - & - & - & - \\
\hline$>12$ weeks & - & - & 20 & $11^{\mathrm{h}}$ & - & - & - & - \\
\hline Total in group & 191 & & 84 & & 212 & & 94 & \\
\hline
\end{tabular}

Comparing a b $P=0.02$, c d $P=0.01$, e f $P=0.025, \mathrm{~g} \mathrm{~h} P=0.004$. Other differences are not statistically different 
The variability was still more than one would wish but less than that of classical double dilution titrations. The largest part of the error could be attributed to differences in the amounts of antigen sticking to the microtitre plates. The antigen contained many membrane proteins. Further purification and definition of specificity are needed.

The early stage of infection at which most sera were taken accounted for the inability to detect no more than $57 \%$ of the men with proved gonorrhoea but it would have had less effect in the women. Increasing the precision of the test and checking the quality of the normal controls should improve the yield.

The results differed from those of other tests (Ward and Glynn, 1972; Buchanan et al., 1973; Oates et al., 1977) in the closeness of antibody levels in men and women, both in cases and in carriers. The ability to pick up symptomless male carriers is particularly interesting. Generally the results primarily indicate a current infection. A previous infection had a slight modifying effect but only if it was recent. If an antibody level of over $15 \mathrm{E}_{\mathrm{cr}}$ was taken as indicating the presence of gonococci, there would be an $84 \%$ chance of being right in men and an $89 \%$ chance in women. This is based on the findings in the normal population. If the same figures were applied to patients attending the STD clinic with conditions other than gonorrhoea, they would give a minimum $5 \%$ failure rate in the detection of gonococci by smear and culture. Even as it is at present, the test could help to diagnose cases, and to a lesser extent it could be used in screening.

Preliminary results have also shown the presence of IgM antibody although in smaller quantities than IgG. It is perhaps relevant that Cohen et al. (1969) using a fluorescence technique detected predominantly IgG antibodies to a surface, labile, gonococcal antigen in experimentally infected volunteers. This antibody appeared at five to seven days, reached a peak at 14 , and then fell. In contrast antibody to gonococcal lipopolysaccharide was predominantly IgM in character (Cohen et al., 1969; Maeland and Larsen, 1971). Apart from duration, the special clinical features associated with higher antibody levels were the presence of rectal symptoms or disseminated infection.

Dr R. R. Willcox has given us encouragement and help over a long period. We thank him, Dr J. R. W. Harris, and the staff of the Praed Street Clinic for allowing us access to their patients and for collecting the blood. We thank the patients, students, and others who willingly gave blood, Miss Angela Evans for her technical assistance, and Dr H. Gaya and $\mathrm{Mr}$ J. Thirlwall for instruction, help, and advice with the computer analysis.

\section{References}

Buchanan, T. M., Swanson, J., Holmes, K. K., Kraus, S. J., and Gotschlich, E. C. (1973). Quantitative determination of antibody to gonococcal pili. Changes in antibody levels with gonococcal infection. Journal of Clinical Investigation, 52, 2896-2909.

Cohen, I. R., Kellogg, D. S., Jr, and Norins, L. C. (1969). Serum antibody response in experimental human gonorrhoea. British Journal of Venereal Diseases, 45, 325-327.

Glynn, A. A., and Ward, M. E. (1970). Nature and heterogeneity of the antigens of Neisseria gonorrhoeae involved in the serum bactericidal reaction. Infection and Immunity, 2, 162-168.

Maeland, J. A., and Larsen, B. (1971). Human serum antibodies reacting with endotoxin from Neisseria gonorrhoeae. British Journal of Venereal Diseases, 47, 269-272.

Nie, N. H., Hall, C. H., Jenkin, J. G., Steinbrenner, K., and Brent, D. H. (1975). Statistical Package for the Social Sciences, second edition. McGraw Hill: New York.

Oates, S. A., Falkler, W. A., Joseph, J. M., and Warfel, L. E. (1977), Asymptomatic females: detection of antibody activity to gonococcal pili antigen by radioimmunoassay. Journal of Clinical Microbiology, 5, 26-30.

Perry, M. B., Daoust, V., Diena, B. B., Ashton, F. E., and Wallace, R. (1975). Lipopolysaccharides of Neisseria gonorrhoeae colony types 1 and 4. Canadian Journal of Biochemistry, 53, 623-629.

Smyth, C. J., Friedman-Kein, A. E., and Salton, M. R. J. (1976). Antigenic analysis of Neisseria gonorrhoeae by crossed immunoelectrophoresis. Infection and Immunity, 13, 1273-1288.

Stead, A., Main, J. S., Ward, M. E., and Watt, P. J. (1975). Studies on lipopolysaccharides isolated from strains of Neisseria gonorrhoeae Journal of General Microbiology, 88, 123-131.

Voller, A., Bidwell, D. E., and Bartlett, A. (1976). Microplate enzyme immunoassays for the immunodiagnosis of virus infections. In Manual of Clinical Immunology, pp. 506-512. Edited by N. R. Rose and $H$. Friedman. American Society for Microbiology: Washington DC.

Ward, M. E., and Glynn, A. A. (1972). Human antibody response to lipopolysaccharides from Neisseria gonorrhoeae. Journal of Clinical Pathology, 25, 56-59.

Watt, P. J., Ward, M. E., and Glynn, A. A. (1971). A comparison of serological tests for the diagnosis of gonorrhoea. British Journal of Venereal Diseases, 47, 448-451. 